\title{
Readiness of Young Malaysian Fishermen to Use Global Positioning System within the Fishing Operation
}

\author{
Mohd Nizam Osman ${ }^{2}$, Siti Zobidah Omar ${ }^{1}$, Jusang Bolong ${ }^{2}$, Jeffrey Lawrence D’Silva ${ }^{1}$ \& Hayrol Azril \\ Mohamed Shaffril ${ }^{2}$ \\ ${ }^{1}$ Institute for Social Science Studies, Universiti Putra Malaysia, Malaysia \\ ${ }^{2}$ Faculty of Modern Language and Communication, Universiti Putra Malaysia, Malaysia \\ Correspondence: Mohd Nizam Osman, Institute for Social Science Studies, Universiti Putra Malaysia, Malaysia. \\ E-mail: majudesa.desa1@gmail.com
}

Received: October 16, 2013 Accepted: April 22, $2014 \quad$ Online Published: June 24, 2014

doi:10.5539/ass.v10n14p1 URL: http://dx.doi.org/10.5539/ass.v10n14p1

\begin{abstract}
Global Positioning System or GPS is an advanced tool that has been widely used in a number of industries including fisheries industry. The main attempt of the present study has much to do with GPS as it aims to identify young Malaysian fishermen readiness to use GPS within their fishing operation. The study is quantitative in nature where a developed questionnaire was used to collect the required data. A total of 240 young fishermen aged between 15 to 40 years old from four fishing areas in Malaysia were selected as the respondents. Overall, it can be concluded that young Malaysian fishermen are ready to use GPS within their fishing operation. However, their readiness can be further improved if aspects such as financial affordability, number of agencies staff, availability of workshop repairing dysfunction GPS and access to GPS are considered by the related agencies.
\end{abstract}

Keywords: young fishermen, readiness, GPS, fishermen development

\section{Introduction}

Making fishermen in developing countries more skillful and knowledgeable on fisheries technology usage is generally considered a very important way to further develop both-the fisheries industry and the main actor of the industry-the fishermen. Global Positioning System or known as GPS is an advanced tool that offers superior functions which overcome several problems associated with conservative ways of catching fish. Though there are abundance of study aim on fisheries technology usage among the fishermen (Omar et al., 2012; Ghee-Thean, 2012; Bolong et al., 2013; Mazuki et al., 2013), not much interest has been placed on their readiness to use advanced technology and the present study aims to fill the gap.

In the recent years, fisheries industry in Malaysia has been well developed. Such success can be measured by the increasing trend recorded for number of marine sources landed and also the number of registered fishermen and vessels. Up to date there are 134,110 registered fishermen compared to just 99,617 in 2007 while the current number of registered vessels is 50,031 compared to just 39,221 in 2007. Moreover, to further attract interest on fisheries industry, every registered fishermen are given monthly allowance worth RM200 (roughly equivalent to USD66) and fuel subsidy which allows them to buy cheaper fuel/diesel. Fishermen in Malaysia are grouped into four categories namely Zone A fishermen (0.1- 5.0 miles nautical), Zone B fishermen (5.1 to 12.0 miles nautical), Zone C0 (12.1 to 30.0 miles nautical) and Zone C2 (more than 30.0 miles nautical). Zone A and Zone B fishermen are also known as coastal fishermen while Zone C0 and C2 fishermen are also known as deep sea fishermen. A majority of fishermen in Malaysia is among the senior fishermen and up to date there is no recent statistic on the number of young fishermen in Malaysia, however, local studies done by Omar et al. (2012), Shaffril et al. (2013) and Mazuki et al. (2013) have consistently shown that nearly $30 \%$ of fishermen within their studies are young fishermen.

To further develop the industry, the government has introduced a number of fisheries technologies such as sonar, echo sounder, GPS, remote sensing, radar and wireless set. Unlike other technologies, GPS can be used by both groups - deep sea and coastal fishermen. The main function of GPS is to mark any location and to navigate the users exactly to the marked location. The main benefit emerged from this superior function is reducing the 
duration of their fishing operation. Compared to traditional fishermen who use to rely on the locations of the star and hill to seek their fishing location, fishermen nowadays can be navigated directly and accurately to their marked fishing locations. This will significantly reduce the time consumed for their fishing operation. A shorter time for fishing operation also means a low cost on fuel and other miscelaneous (e.g. ice). In addition to this, a shorter duration also denotes the chances of fishermen to save their energy and spend more time with their family (Abu Hassan et al., 2011).

Superior technology is always linked to the younger generation. Compared to the older generation who is heavily linked with conventional ways of conducting their fishing operation, young fishermen on the other hand, is well known with their eagerness, readiness and compatibility to use advanced gadgets - such scenario is not surprising as such inventions help them much in their daily activities and fit with their interest and ability (Dittmar, 2005; Macro Analysis and Consumer Research Organization, 2004). Furthermore, as high technical complication will affect the frequency of technology usage (Cahill et al., 2007), things are going in different ways for user friendly technology such as GPS-as it involves simple procedures- just by clicking one button, it can navigate them accurately and directly to their intended areas. Despite these benefits, however, there are still fishermen who reluctance to embrace technology in their fishing operation and problems related to financial, lacking of organizations and staffs supports, inadequate number of staffs and inadequate number of relevant trainings are among the identified causes (Flores, 2003; Malamud \& Pop-Eleches, 2010).

Although fisheries technology is there for the fishermen, the issue that commonly raised is whether they are ready to use it or not? Can and will they use it? Are the existing agencies and infrastructures will support usage of technology among them? In response to such query, this study has come out with its main objective which is to identify young fishermen readiness towards GPS usage within their fishing operation.

\section{Methodology}

Through a multi stage simple random sampling, a total of 240 young fishermen from four areas-Kuala Besut (east coast zone), Mersing (southern zone), Langkawi Island (northern zone) and Pangkor Island (central zone) were selected as the respondents. Young fishermen within this study is referring to the youth fishermen whose aged is between 15 to 40 years old. To have this age group is neccessary as it is in line with youth definition of Ministry of Youth and Sports Malaysia. The study is using questionnaire to collect the data needed. All of the questions included were based on review of literature and questions of past studies. For each of the question (except for demographic part), the respondents were given a five likert-like scale ranging from 1 (strongly disagree) to 5 (strongly agree). The questionnaire was constructed based on five parts namely demographic, young fishermen readiness, individual readiness, infrastructure readiness and agencies readiness (Table 1).

Table 1. The questionnaire

\begin{tabular}{|c|c|c|c|}
\hline Part & Number of questions & Option of answer & \\
\hline Demographic part & 9 & Closed ended and open ended & \\
\hline $\begin{array}{l}\text { Readiness } \quad \text { (young } \\
\text { fishermen) }\end{array}$ & 5 & Likert-scale (five) & Refers to respondents readiness \\
\hline Readiness (Individual) & 5 & Likert-scale (five) & $\begin{array}{l}\text { Refers to perception of the } \\
\text { respondents on their colleague } \\
\text { readiness }\end{array}$ \\
\hline $\begin{array}{l}\text { Readiness } \\
\text { (Infrastructure) }\end{array}$ & 5 & Likert-scale (five) & $\begin{array}{l}\text { Refers to available infrastructure that } \\
\text { can support their GPS usage }\end{array}$ \\
\hline Readiness (Agencies) & 6 & Likert-scale (five) & $\begin{array}{l}\text { Refers to available agencies that can } \\
\text { support their GPS usage }\end{array}$ \\
\hline
\end{tabular}

After completed the questionnaire, it was then pre-tested among 30 respondents at Kuala Terengganu and Kuala Paka. Most of the parts have exceeded the recommended cronbach alpha value by Nunnaly (1978) which is 0.700 . For the part that didn't exceed 0.700 , some actions have been taken to further strengthen it (refer to Table 2). 
Table 2. Pre-test result

\begin{tabular}{|c|c|c|}
\hline Part & Cronbach alpha value & Actions taken (for part that recorded less than 0.700 ) \\
\hline $\begin{array}{l}\text { Readiness (young } \\
\text { fishermen) }\end{array}$ & .800 & - \\
\hline $\begin{array}{l}\text { Readiness } \\
\text { (Individual) }\end{array}$ & .857 & - \\
\hline $\begin{array}{l}\text { Readiness } \\
\text { (Infrastructure) }\end{array}$ & $.697^{*}$ & $\begin{array}{l}\text { Though exclusion of question no } 3 \text { within this part will increase the value } \\
\text { more than } 0.700 \text {, however, the researchers have decided to maintain and } \\
\text { re-phrase the question to further enhance respondents' understanding, }\end{array}$ \\
\hline $\begin{array}{l}\text { Readiness } \\
\text { (Agencies) }\end{array}$ & .914 & - \\
\hline
\end{tabular}

After completed the pre test process, the actual data collection process taken its place. The data collection was conducted in five months period (from February 2013 till July 2013). The data collection process was assisted by trained and experienced enumerators and monitored by the researchers. All of the analyses performed were using SPSS. For categorizing the levels of their readiness, the mean score gained for each part/statement was categorized into three levels based on the calculation of 5 (number of maximum mean score) $/ 3$ (number of levels). The calculation resulted in three levels namely low (mean score 1.00 to 2.33), moderate (mean score 2.34 to 3.67) and high (mean score 3.68 to 5.00 ).

\section{Results}

Table 3 demostrates the demographic data of the respondents. A huge majority of the respondents surveyed were male and according to Gidarakou (1997) physical demand and family commitment have minimized female involvement in agriculture actvities. The mean score for age was 31.3 years where a majority of them were included in the age group of 36-40 years old. Fisheries industry seem fail to attract involvement from higher education achiever (Omar et al., 2012; Bolong et al., 2013; Shaffril et al., 2013) and a similar secanario can be found within the scope of this study where only $4.5 \%$ of the respondents possessed tertiary level of education and slightly more than one third of them (34.6\%) possessed SPM/MCE/SPMV level of education. Man (2008) have explained the scenario by stating that higher education achiever seem to express less interest on agriculture activities as they consider it as a second class job or just an alternative way of adding their income. A total of $51.3 \%$ of the respondents have 4-6 household members. The mean score for income per month was RM941.5 (roughly equivalent to USD313) which exceeded the poverty level set by rhe Economic Planning Unit of Malaysia which is RM720 (roughly equivalent to USD240), however, it should be taken into consideration that some of the respondents were still earning below RM500 (roughly equivalent to USD166) per month. The respondents surveyed can be considered as experienced fishermen as the mean score recorded for experience as a fisherman was 12.2 years and even (32.5\% of them possessed more than 16 years of experience. A total of $37.9 \%$ of the respondents have 2-3 crew members within their vessels. The mean score recorded for days spent at the sea for fishing operation per month was 18.7 days and to have such number is not surprising as one of the requirements for being a registered fisherman was to conduct at least 120 days of fishing operation in a year. In line with findings of other studies (Omar et al., 2012; Mazuki et al., 2013; Bolong et al., 2012), a majority of the respondents of this study were coastal fishermen $(86.3 \%)$.

In term of their readiness on GPS usage, out of four readiness aspects studied, a total of two aspects recorded a high level of readiness namely young fishermen readiness and individual readiness. From the results, the young fishermen are seen as ready to use GPS as they already knew that GPS can be used within their fishing operation and offer a number of benefits to them. Moreover, their readiness are supported by their skills, willingness and ability to use advanced technology such as GPS. Although almost all of the statements related to fishermen and individual readines recorded a high level of mean score, it should be taken into consideration that one statement related to access to GPS recorded a moderate level of mean score. 
Table 3. Demographic data of the respondents

\begin{tabular}{|c|c|c|c|}
\hline Variable & Frequency & Percentage & Mean \\
\hline \multicolumn{4}{|l|}{ Gender } \\
\hline Male & 237 & 98.8 & \\
\hline Female & 3 & 1.2 & \\
\hline Age (years) & & & 31.3 \\
\hline$<25$ & 62 & 25.8 & \\
\hline $26-30$ & 44 & 18.3 & \\
\hline $31-35$ & 42 & 17.5 & \\
\hline $36-40$ & 92 & 38.3 & \\
\hline \multicolumn{4}{|l|}{ Education achievement } \\
\hline Never been to school & 21 & 8.8 & \\
\hline Primary school & 61 & 25.4 & \\
\hline PMR/LCE/SRP & 64 & 26.7 & \\
\hline SPM/MCE/SPMV & 83 & 34.6 & \\
\hline Tertiary level & 11 & 4.5 & \\
\hline \multicolumn{4}{|l|}{ Number of household } \\
\hline $1-3$ & 56 & 23.3 & \\
\hline $4-6$ & 126 & 51.3 & \\
\hline$>6$ & 58 & 25.4 & \\
\hline Income (from fisheries activity) (RM) & & & 941.5 \\
\hline$<500$ & 55 & 22.9 & \\
\hline $501-750$ & 46 & 19.2 & \\
\hline $751-1000$ & 91 & 37.9 & \\
\hline$>1001$ & 48 & 20.0 & \\
\hline Experience as a fisherman (years) & & & 12.2 \\
\hline$<5$ & 68 & 28.3 & \\
\hline $6-10$ & 48 & 20.0 & \\
\hline $11-15$ & 46 & 19.2 & \\
\hline$>16$ & 78 & 32.5 & \\
\hline \multicolumn{4}{|l|}{ Number of crew members } \\
\hline $0-1$ & 71 & 29.6 & \\
\hline $2-3$ & 106 & 44.2 & \\
\hline $4-5$ & 16 & 6.6 & \\
\hline$>5$ & 47 & 19.6 & \\
\hline Days spent for fishing operation per month & & & 18.7 \\
\hline$<15$ & 75 & 31.3 & \\
\hline $16-20$ & 85 & 35.4 & \\
\hline $21-30$ & 80 & 33.3 & \\
\hline \multicolumn{4}{|l|}{ Catching area } \\
\hline Zone A & 161 & 67.1 & \\
\hline Zone B & 46 & 19.2 & \\
\hline Zone $\mathrm{C} 0$ and $\mathrm{C} 2$ & 33 & 13.7 & \\
\hline
\end{tabular}

Based on the recorded overall mean score, it can seen that the fishermen viewed the available infrastructure and related agencises as moderately ready to assist them in GPS usage. Specifically, the available infrastructure are seen ready to support GPS usage especially on the strength of the satellite signal for the GPS. However, it should be noted that statement related to unavailability of workshops for them to repair dysfunction GPS recorded the lowest mean score. The fishermen views agencies are less ready to help them in GPS usage particularly with regard to inadequate number of agencies staffs and training and seminars available to them. To have staffs such as extension officers is vital to accelerate the fishermen learning process on GPS. Such lacking will tone down the information sharing and dissemination processes between the agencies and the community and this in in line with findings in Table 4 where fishermen claimed that there is difficulties to communicate with agencies officers to share information. 
Table 4. Young fishermen readiness towards GPS usage

\begin{tabular}{|c|c|}
\hline Young fishermen readiness & Mean score \\
\hline Overall mean score & 3.80 \\
\hline The young fisherman know GPS can be used in their fishing activities & 4.05 \\
\hline The young fishermen are able to manage their time in using GPS & 3.85 \\
\hline The young fisherman had enough skills to use GPS & 3.68 \\
\hline Access to GPS is not a big problem to the young fishermen & 3.48 \\
\hline I think the young fisherman is ready to use GPS & 3.96 \\
\hline Individual readiness & Mean score \\
\hline Overall mean score & 4.09 \\
\hline I know that GPS technology can be used as a tool to help fishing activities & 4.20 \\
\hline I am willing to use GPS because it is useful in the process of learning and development & 4.12 \\
\hline I think now is the right time to promote the use of GPS among young fishermen & 4.14 \\
\hline I am willing to involve the use of GPS in fishing activities & 4.20 \\
\hline I have sufficient ability to use GPS. & 3.79 \\
\hline Infrastructure readiness & Mean score \\
\hline Overall mean score & 2.86 \\
\hline Existing infrastructure in the area to support the use of GPS among young fishermen & 2.88 \\
\hline Technical support for the use of GPS in this area is sufficient & 2.70 \\
\hline There are shops that can repair dysfunction GPS & 2.34 \\
\hline The government has made plans in improving the ICT infrastructure in this area & 2.55 \\
\hline Satellite signal reception in this area is satisfactory & 3.85 \\
\hline Agencies readiness & Mean score \\
\hline Overall mean score & 2.75 \\
\hline The administration recognizes the use of GPS & 3.47 \\
\hline Related agencies promotes the use of GPS & 2.95 \\
\hline Related agency has a plan to increase the use of GPS among young fishermen in the future & 2.80 \\
\hline Related agencies provide training / seminars regarding the use of GPS among young fishermen & 2.39 \\
\hline The related agencies has sufficient officers to assist young fishermen on the use of GPS & 2.36 \\
\hline The related agencies know to use fishing technology such as GPS & 2.55 \\
\hline
\end{tabular}

\section{Discussion and Recommendation}

Making young fishermen in developing countries such as Malaysia ready to use fisheries technology such as GPS is generally considered as a crucial path to development. This paper has focused on several readiness aspects of the young fishermen in Malaysia that might affect their adoption of GPS within their fishing operation. It offers a number of significance, firstly, it contributes to the existing body of knowledge where new information on young fishermen readiness to use GPS can be gained. Secondly, it contributes to practices in a sense that it gears to key areas that influence readiness of young fishermen to use GPS which can lead to a better fishing practice through a better usage of fisheries technologies. Thirdly, it contributes to the policy where data gained can assists the concern parties in constructing concrete strategies that are in line with needs, interests and ability of the young fishermen.

Based on the mean score recorded for all of the readiness aspects (range from 2.75 to 4.09), it can be seen that young fishermen are ready to use GPS. A high level of readiness among the fishermen can be caused by their eagerness, readiness and compatibility to use advanced gadgets as such inventions help them much in their daily activities and fit with their interest and ability (Dittmar, 2005; Macro Analysis and Consumer Research Organization, 2004). Furthermore, as high technical complication will negatively impact the frequency of technology usage (Cahill et al., 2007), things are going in different ways for GPS usage as it involves simple procedures- as by clicking one button, it can navigate them to the marked fishing areas. Although fishermen are seen as ready to use GPS, yet, some readiness aspects related to financial, number of staff, availability of GPS workshop and access to GPS can be further improved to further enhance their readiness and the present article has come out with a number of recommendations.

First, although young fishermen readiness for GPS usage is there, what is still lacking is their financial 
affordability. To overcome this, financial aid by the related parties (e.g. technology subsidy) is seen as an effective solution. Malamud and Pop-Eleches (2010) in their study have demonstrated how the poor have significantly increased their usage of technology after they possessed the technology through the subsidy. Such finding has been supported by Flores (2003) who found financial sources as an influential factor for technology usage and stressed that those with wider financial sources seems to have a stronger financial ability to posses technology thus enhance the possibilities of them to use the technology more.

Second, to have adequate number of staffs in any agriculture organization is crucial particularly for the extensions works. Lacking of staffs will result in ineffective process of information sharing and dissemination between the related agencies and the young fishermen. It will then result in problems related lack of technical support from the related parties, difficulties for the fishermen to share or get the related GPS information from related officers and less awareness among the young fishermen on the importance and benefits of GPS usage. It is understood that financial constraint might obstrcut the related agencies from hiring more officers and it is recommended here that influential members of the community to be hired as the informal officers from the agencies that can voluntarily run the extension works. Any extension works regarding technology usage run by local members can be successful based on the fact that higher involvement from fishermen are expected if a program is run by local people and influential people such as fishermen colleagues, jetty leaders and skippers (Shaffril et al., 2013; Mazuki et al., 2013).

Third, it is important to have a workshop repairing dysfunction GPS which can help young fishermen to continue their fishing operations. Apart from having a GPS, to maintain it also important where any technical complication related to GPS might reduce of interest on technology usage. Fourth, access to GPS can be provided by the related parties by offering technology subsidy to the young fishermen. By having financial capacity they can possess GPS and use it in their fishing routine. Moreover, programs such as courses and seminars might be useful to expose and educate fishermen on GPS usage and its benefits for fisheries industry.

\section{Conclusion}

It can be concluded that young fishermen in Malaysia are ready to use GPS, however, there are several aspects that should be considered by the concern parties to further improve their readiness. The findings able to fill the gap in the literature as most of the literatures focus on technology usage rather than their readines to use it. As development benefits the community and the use of GPS within fishing operation is critical to their performance, the present article studies and accesses on young fishermen readiness to use GPS for taking one particular step. Although the recommendations made are limited to Malaysian settings, it can at least be considered for other countries that possess a similar socio-economic context.

The study consists of several limitation. First, the study was conducted only at the four selected states namely Terengganu, Kedah, Johor and Perak although all there are registered fishermen at all the states in Malaysia. Furthermore, the limitation is regarding the number of respondents involved in which in the case of the study only a total of 240 young fishermen are chosen. The next limitation is imbalance number of male and female fishermen as the fisheries industry is hugely dominated by male. Relating to these limitations, the results might be different if the study is conducted at the other states, involving a larger number of respondents and have a balance number of respondents in term of male and female respondents.

\section{References}

Abu Hassan, M., Shaffril, H. A. M., D’Silva, J. L., Omar, S. Z., \& Bolong, J. (2011). Fishermen and ICT: Towards creating knowledgeable fishermen in Malaysia. Australian Journal of Basic and Applied Science, 5(9), 457-469.

Bolong, J., Omar, S. Z., Shaffril, H. A. M., D'Silva, J. L., \& Abu Hassan, M. (2012). Communication Technologies and Fishermen: Lesson Learned from Langkawi Island and Kuala Besut. Science Series Data Report, 4(5), 2-12.

Cahill, S., Begley, E., Faulkner, J. P., \& Hagen, I. (2007). "It gives me a sense of independence"-Findings from Ireland on the use and usefulness of assistive technology for people with dementia. Technology and Disability, 19, 133-142.

Dittmar, H. (2005). Compulsive buying-a growing concern? An examination of gender, age, and endorsement of materialistic values as predictors. British Journal of Psychology, 96, 467-491. http://dx.doi.org/10.1348/ $000712605 X 53533$

Flores, C. (2003). Measuring the relationship between ICT use and income inequality in Chile. University of Texas Inequality Project. Working Paper 26. Retrieved July 31, 2013, from http://utip.gov.utexas.edu/ 
papers/utip_26.pdf

Ghee-Thean, Latif, I. A., \& Hussein, M. A. (2012). Does technology and other determinants effect fishing efficiency? An application of stochastic frontier and data development analyses on trawl fisheries. Applied Science, 12(1), 48-55. http://dx.doi.org/10.3923/jas.2012.48.55

Gidarakou, I. (1997). Young women's attitude towards agriculture and women's new roles in the Greek countryside: A first approach. Journal of Rural Studies, 15(2), 147-158. http://dx.doi.org/10.1016/ S0743-0167(98)00054-0

Macro Analysis and Consumer Research Organization (MACRO). (2004). Study on Mobile Phone Usage among the Teenagers and Youth in Mumbai. Retrieved June 27, 2013, from http://www.itu.int/osg/spu/ni/ futuremobile/socialaspects/IndiaMacroMobileYouthStudy04.pdf

Malamud, O., \& Pop-eleches, C. (2010). Home computer use and the development of human capital. The Quarterly Economics, 126(2), 987-1027. http://dx.doi.org/10.1093/qje/qjr008

Man, N. (2008). Youth farmers' perception towards agriculture and the needs for agriculture education. Malaysia Journal of Youth Development, 1, 99-114.

Mazuki, R., Omar, S. Z., Bolong, J., D’Silva, J. L., \& Shaffril, H. A. M. (2013). Social Influence in Using ICT among Fishermen in Malaysia. Asian Social Science, 9(2), 135-138. http://dx.doi.org/10.5539/ass.v9n2p135

Omar, S. Z., Shaffril, H. A. M., D’Silva, J. L., Bolong, J., \& Abu Hassan, M. (2012). Usage of Offshore ICT among Fishermen in Malaysia. Journal of Food, Agriculture and Environment, (3\&4), 1315-1319.

Shaffril, H. A. M., Abu Samah, B., D’Silva, J. L., \& Yassin, S. M. (2013). The process of social adaptation towards climate change among Malaysian fishermen. International Journal of Climate Change Management and Strategies, 5(1), 38-53. http://dx.doi.org/10.1108/17568691311299354

\section{Copyrights}

Copyright for this article is retained by the author(s), with first publication rights granted to the journal.

This is an open-access article distributed under the terms and conditions of the Creative Commons Attribution license (http://creativecommons.org/licenses/by/3.0/). 